\title{
Liver transplantation as a treatment for Wilson's disease with neurological presentation: a systematic literature review
}

\author{
Tomasz Litwin ${ }^{1}$ (1) Jan Bembenek ${ }^{2} \cdot$ Agnieszka Antos $^{1} \cdot$ Adam Przybyłkowski $^{3} \cdot$ Marta Skowrońska $^{1}$. \\ Iwona Kurkowska-Jastrzębska ${ }^{1} \cdot$ Anna Członkowska ${ }^{1}$
}

Received: 7 October 2021 / Accepted: 13 January 2022 / Published online: 26 January 2022

(c) The Author(s) 2022

\begin{abstract}
Introduction Wilson's disease (WD) is a potentially treatable, genetic disorder of copper metabolism, with survival similar to healthy populations if controlled. However, in almost 50\% of WD patients, neurological symptoms persist despite treatment, and in up to $10 \%$ of patients, neurological deterioration is irreversible. International guidelines on WD treatment do not recommend liver transplantation (LT) as a treatment for neurological symptoms in WD. However, such treatment has been assessed in retrospective analyses, case and series reports. We aimed to systematically assess all available evidence on the effectiveness and safety of LT in WD patients with neurological presentation.

Methods This systematic literature review was performed according to Preferred Reporting Items for Systematic Reviews and Meta-Analyses (PRISMA) guidelines. Studies were identified by searching the PubMed database (up to 6 April 2021) and by screening reference lists.

Results Based on the systematic literature review, 48 articles were identified, showing outcomes of LT in 302 WD patients with neurological symptoms. Of these patients, major improvement was found in 215 cases $(71.2 \%)$, with no difference in neurological status before and after LT in 21 cases (6.9\%). There were 29 deaths (9.6\%), neurological worsening in 24 cases (7.9\%), and 13 cases (4.3\%) were lost to follow-up.

Conclusions The results suggest that LT is a promising method of WD management in patients with severe, neurological symptoms, particularly if the patient has not responded to pharmacological de-coppering treatment. Further studies of LT in these patients are warranted.
\end{abstract}

Keywords Wilson's disease $\cdot$ Liver transplantation $\cdot$ Copper $\cdot$ Neurological symptoms $\cdot$ Systematic review

\section{Introduction}

Wilson's disease (WD) is a genetic disorder characterized by pathological copper accumulation in various organs (mainly liver and brain) with damage to the affected organs

Tomasz Litwin and Jan Bembenek contributed equally to this work.

Tomasz Litwin

tomlit@medprakt.pl

1 Second Department of Neurology, Institute of Psychiatry and Neurology, Sobieskiego 9, 02-957 Warsaw, Poland

2 Department of Clinical Neurophysiology, Institute of Psychiatry and Neurology, Warsaw, Poland

3 Department of Gastroenterology and Internal Medicine, Medical University of Warsaw, Warsaw, Poland and clinical symptoms related to injury (mainly hepatic and/ or neurological) [1-4].

WD is caused by mutations in $A T P 7 B$, a gene located on chromosome 13, which encodes the copper-transporting ATPase, ATP7B, which is abundant in the liver and is also found in the brain, placenta, kidneys, lungs and heart [1-3]. Due to ATP7B dysfunction, copper accumulates in hepatocytes and cannot be incorporated into cuproproteins (e.g., ceruloplasmin) and removed into the systemic circulation $[1,3]$. Mitochondria are particularly sensitive to copper overload [1-3]. Copper-induced lipid peroxidation leads to mitochondria membrane damage, subsequent disruption of respiratory chain enzymes, and finally hepatocyte necrosis, with release into the circulation of free non-ceruloplasminbound copper (NCC) [1-5].

Treatment of WD is based on drugs that induce negative copper balance: (1) chelators (d-penicillamine or trientine) 
promote increased urinary copper excretion; (2) zinc salts inhibit copper absorption from the digestive tract; and (3) complexors (molybdenum salts, currently in clinical trials) decrease absorption of copper from the digestive tract, promoting excretion of copper into bile, and form complexes with copper and albumins to reduce NCC levels in the systemic circulation [1-5].

Mortality rates in patients with WD are similar to healthy populations if the disease is diagnosed early and appropriately treated [6-12]. In almost $85 \%$ of treated WD patients, clinical improvement is observed [13]. However, in 50\% of patients with neurological manifestations, clinical symptoms persist, and irreversible neurological deterioration occurs in almost $10 \%$ of patients. These findings contribute to the search for other strategies to treat severe neurological WD presentation, such as symptomatic treatments and also liver transplantation (LT) $[3,6-12,14,15]$.

LT is currently recommended only to WD patients with acute liver failure or decompensated liver cirrhosis (despite anti-copper treatment) $[1-5,15]$. LT in neurological presentations of WD is still being debated [15]; however, it seems an attractive method as, in contrast to autoimmune hepatitis, primary sclerosing cholangitis, primary biliary cirrhosis, viral hepatitis or alcohol liver disease, WD will not recur in the transplanted organ [1]. There are several retrospective analyses of registries, series reports, and case reports published on LT in WD (including patients with neurological symptoms) as well as small prospective analyses [16-73]. Here, we describe results from the first-ever systematic review of the literature analyzing the efficacy of LT in the treatment of neurological symptoms of WD.

\section{Materials and methods}

\section{Search strategy and eligibility criteria}

This systematic review was performed in concordance with international accepted criteria of the Preferred Reporting Items for Systematic Reviews and Meta-analyses (PRISMA) statement [74].

We searched the PubMed database (up to 6 April 2021) for original studies (prospective and retrospective), as well as case and series reports analyzing the efficacy of LT as a treatment option for WD patients with neurological phenotypic manifestation. Search terms included ("Wilson's disease" and "liver transplantation" and "neurological symptoms"), ("Wilson's disease" and "liver transplantation" and "neurology"), and ("Liver transplantation and neurological Wilson's disease"). Studies eligible for further analysis were: (1) conducted with humans; (2) original studies (prospective or retrospective); (3) case and series reports of the patients with neurological manifestation of WD who have had LT; and (4) in English language. Review articles and studies describing the neurological outcome of LT in patients with other etiologies of liver failure were excluded. The reference lists of extracted publications were also searched.

All identified studies were analyzed and verified independently by all authors to confirm the inclusion criteria, and were grouped as: (1) prospective studies which aimed to present the efficacy of LT in the treatment of neurological symptoms of WD; (2) retrospective studies presenting data from national or center-based LT registries which presented additionally neurological WD patients and their outcome after LT; (3) series reports; and (4) case reports of LT in neurological WD patients.

\section{Results}

In total, 354 records were retrieved: 352 from PubMed searches and 2 for the detailed review of the reference lists [16, 18] (Fig. 1). Following duplicate removal, 198 publications remained. The title, abstracts and full texts were then screened for relevance, removing another 150 records. Finally, 48 full-text articles of LT in 302 WD patients with neurological symptoms were included in the analysis. No prospective studies were identified, and there were 24 retrospective studies on patients with WD treated with LT; 23 of them were additional analyses of neurological symptoms in WD patients undergoing LT due to liver failure and only 1 was an analysis of neurological symptoms after LT in WD patients transplanted due to neurological deterioration (Table 1). There were 24 case reports and case series describing the WD patients with neurological presentation who had LT (Supplementary Table 1). The methodology for assessing neurological symptoms differed, also the brain magnetic resonance imaging (MRI) data of these patients were of different quality. Moreover, different neurological scales were used, making it impossible to perform metaanalyses of the reviewed studies.

The cumulative survival rate in studies was $90.4 \%$ at the end of follow-up of all included studies. Most studies, case series and case reports reported favorable effects, with major improvement or complete neurological recovery in $215 \mathrm{WD}$ cases $(71.2 \%)$. In 21 cases $(6.9 \%)$, there was no difference in neurological status before and after LT. There were 29 deaths $(9.6 \%), 24$ cases of de novo neurological deterioration $(7.9 \%$; mostly related to immunosuppressive treatment after LT), and 13 cases (4.3\%) were lost to follow-up. There was a clear trend toward better results of LT in more recent studies compared with older studies, with older studies suggesting worse outcome in WD patients with neurological presentations [50], which was not confirmed in newer publications (Table 1 and Supplementary Table 1). For example, 


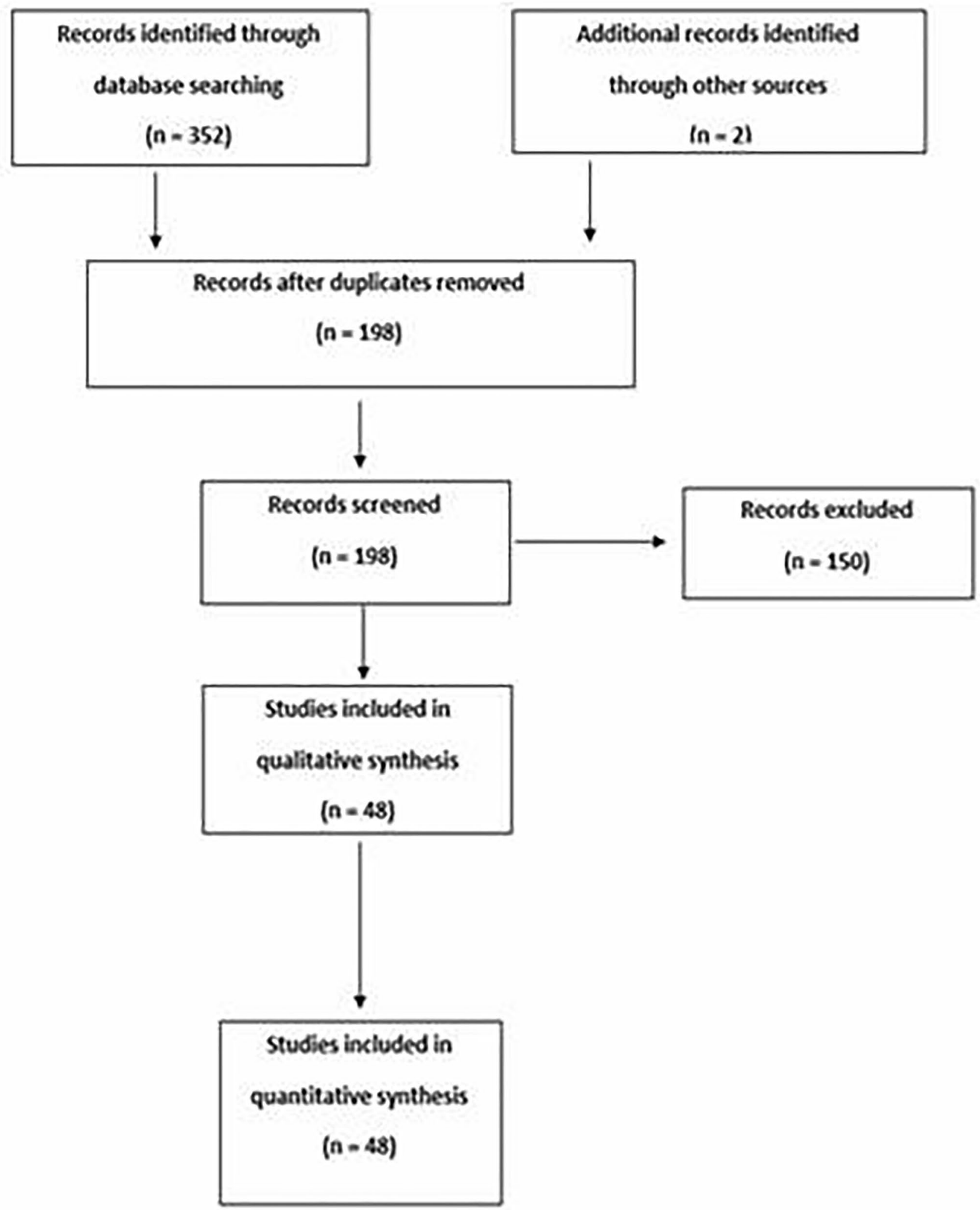

Fig. 1 PRISMA search diagram. A total of 352 articles were found during the initial screening and 48 articles were included in the qualitative synthesis 


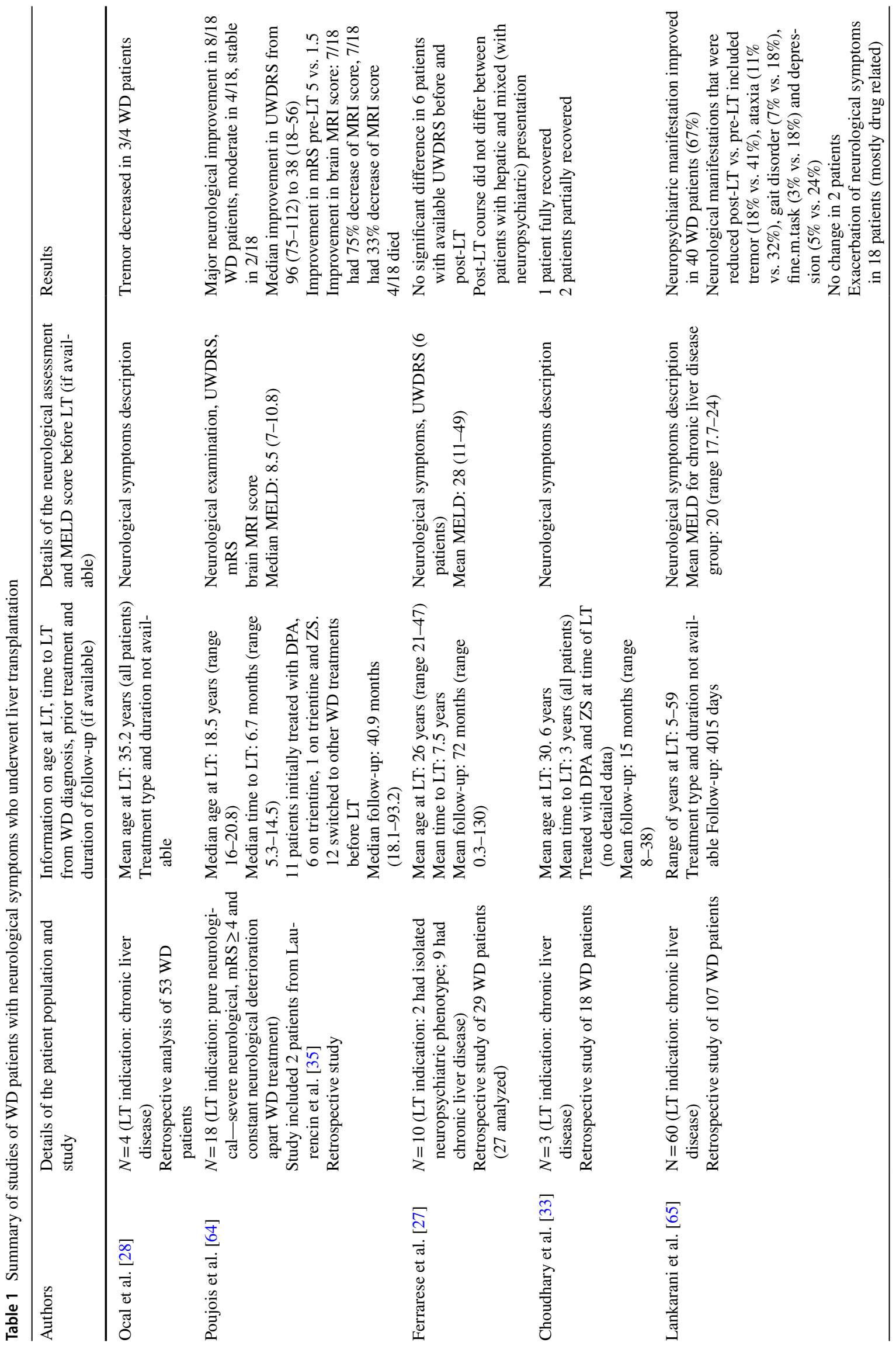




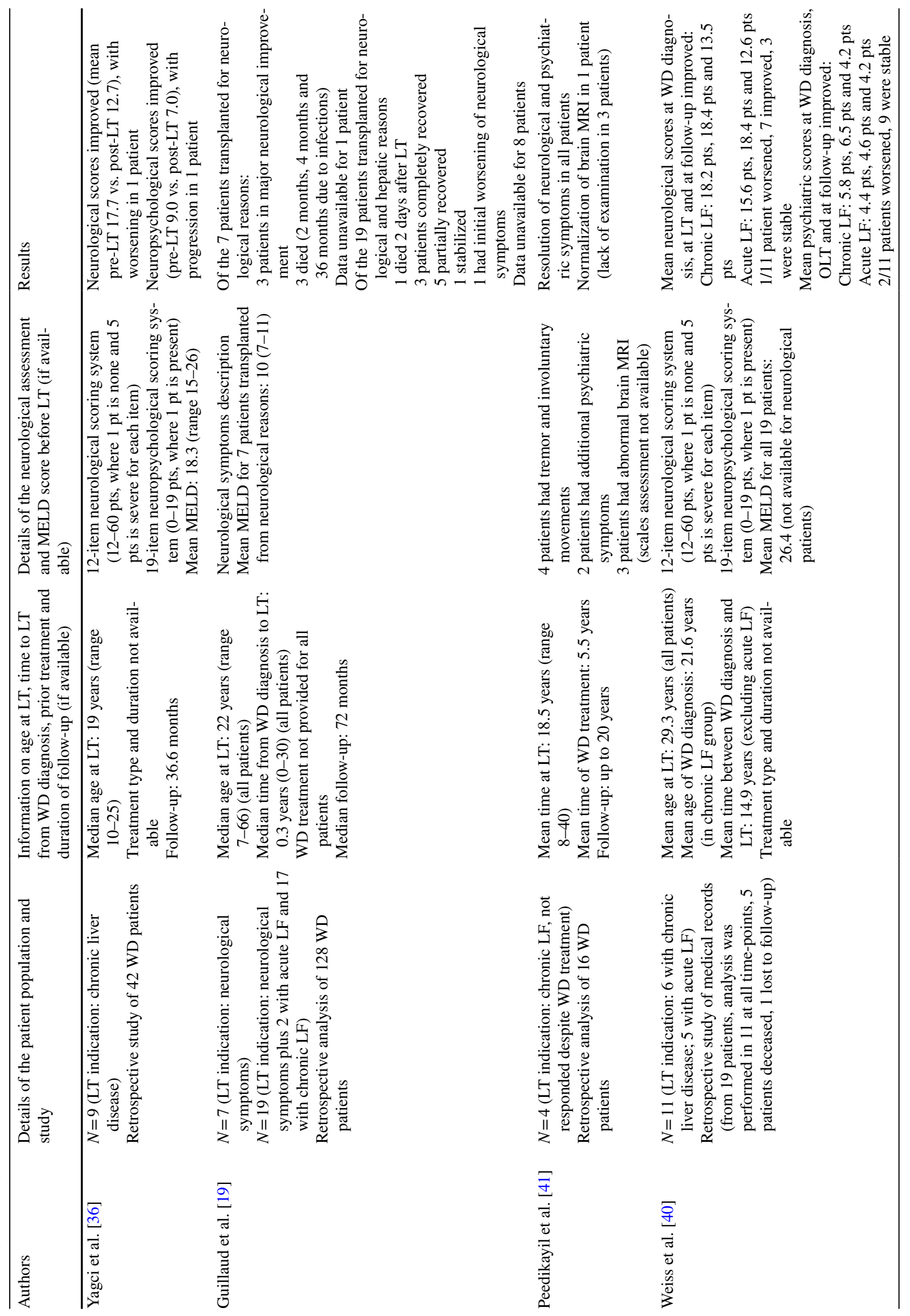




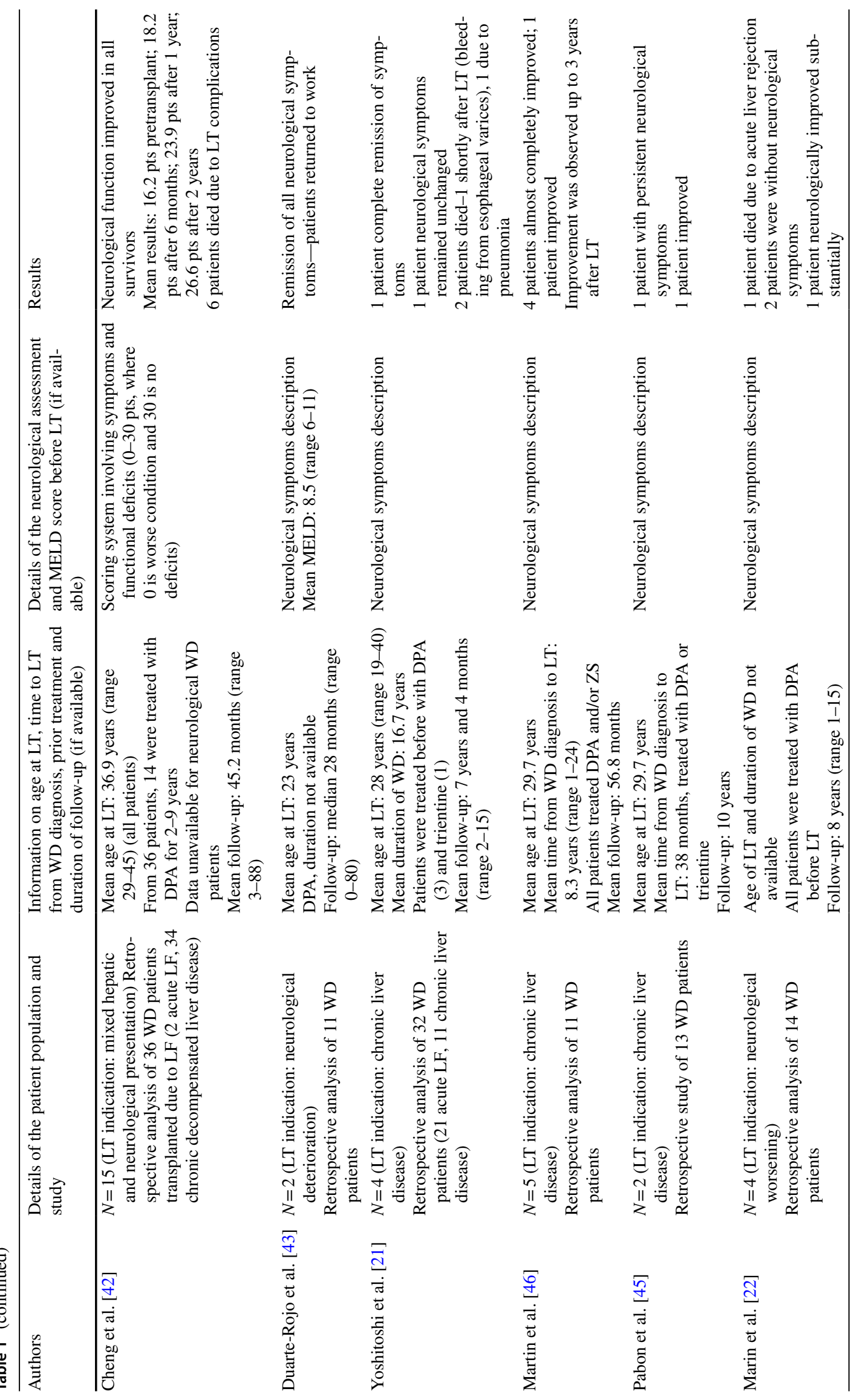




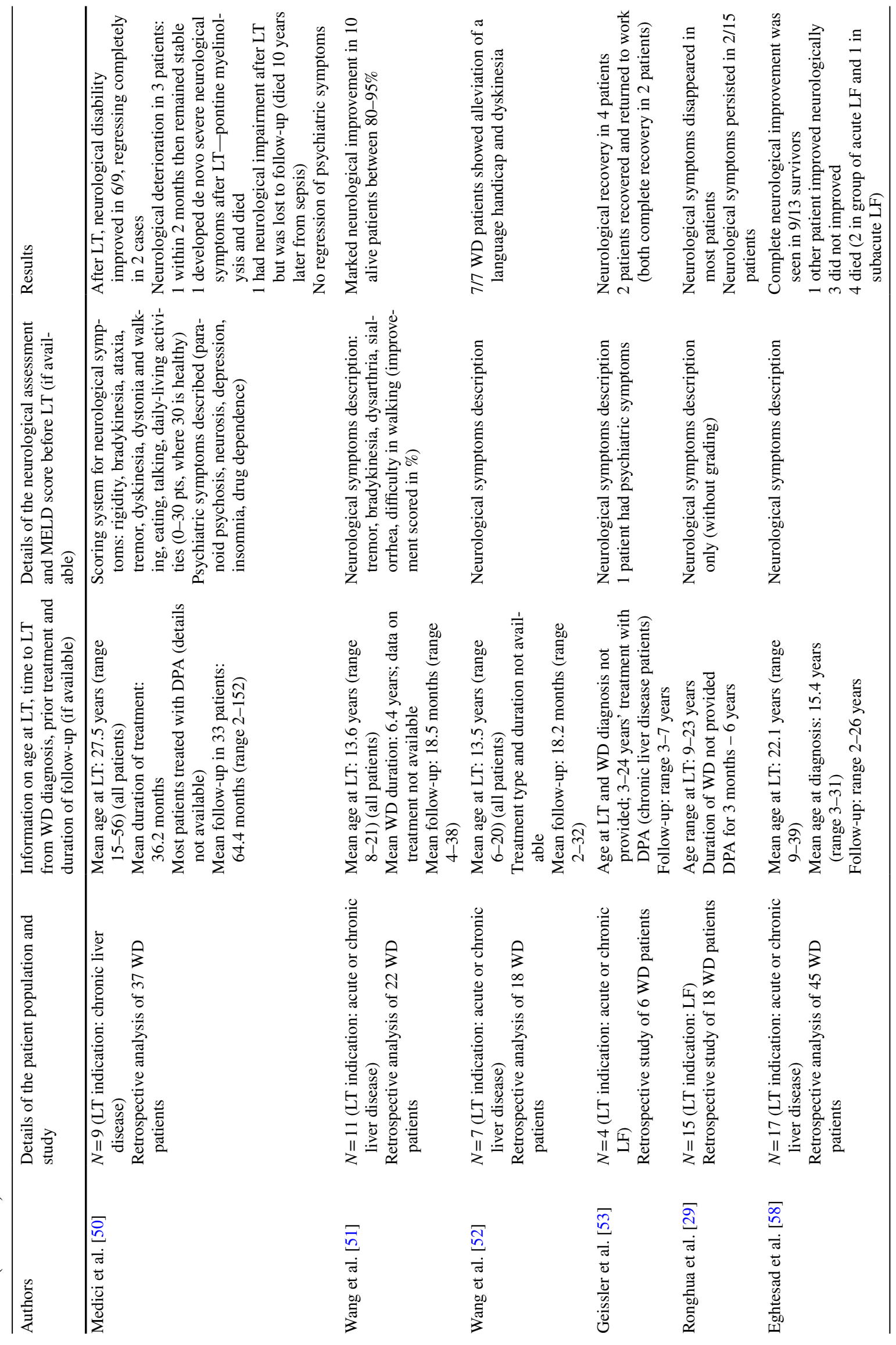




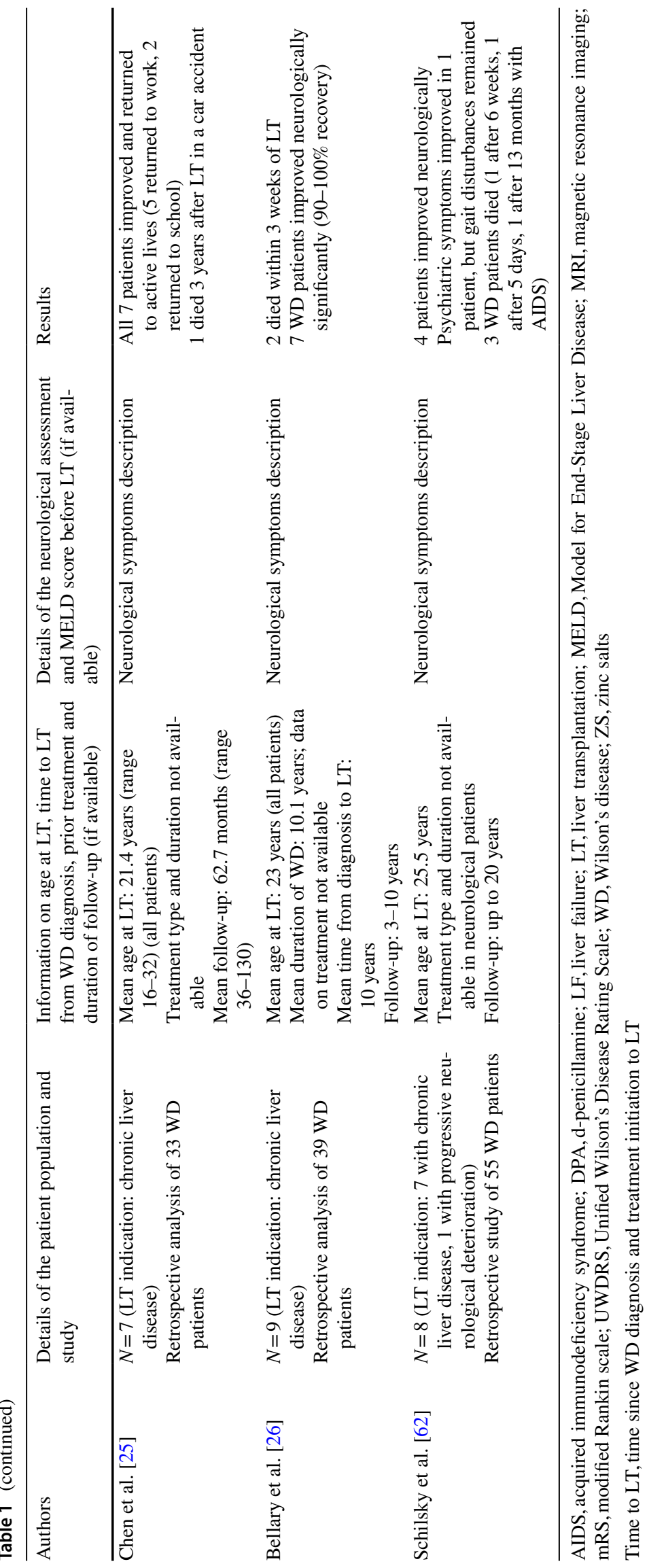


Lankarani et al. [65] reported improvement of neurological symptoms in almost $67 \%$ of transplanted WD patients.

Out of 24 cases and series reports of 32 WD patients, $25(78 \%)$ independent WD patients showed substantial improvement in neurological status and dependence within 4 weeks to 10 years after LT. In four cases (12.5\%), there was slight neurological improvement; however, patients were dependent. There was also one deterioration [61] and two deaths $[31,49]$. In one of those patients, the patient showed neurological improvement, but then the patient died due to aneurysm rupture [31].

Taking into account the progress in transplantation during the time (surgery techniques as well as immunosuppression and global patient healthcare), we additionally analyzed cases according to when LT was performed: 15 patients underwent LT up to 2000 and 17 had LT after 2000. In the pre-2020 group, we found three cases of slight neurological improvement (patients remained functionally dependent) $[31,32,60]$ and one case of neurological deterioration $(1 / 15)$ [61]. There were no neurological deteriorations described in the group transplanted after 2000. Analyzing deaths after LT, one case was reported before 2000 [31] and one after [49].

The analysis of brain MRI in patients after LT retrieved from hepatological registries was very limited, apart from the study by Poujois et al. [64], which documented a correlation between regression of MRI changes and clinical improvement (Table 1). We found assessment of the brain MRI changes in case and series reports for only 10 out of 32 patients [24, 35, 38, 48, 55-57, 61]. In nine cases, regression of disease was observed [24, 35, 38, 48, 55-57], and in one, there was worsening that corresponded with clinical neurological deterioration [61]. The clear correlations between radiological changes and neurological status were adequately presented only in case reports. However, the methodology (lack of semiquantitative scales, different MRI technology) limited drawing conclusions from these results.

\section{Discussion}

To our best knowledge, this is the first systematic review of the literature that presents the effectiveness of LT in the treatment of neurological manifestations of WD.

Based on international recommendations, LT is recommended only for WD patients with acute liver failure or in decompensated liver cirrhosis [1-5]. All patients should also fulfill modified Nazer index as a prognostic factor for survival in WD patients and LT [1-5]. According to international registries, about $1.5 \%$ of LT are performed due to WD. Based on WD registries, around 5\% of WD patients are treated with LT, mostly due to acute liver failure [1-3].
The first experiences with LT in WD were reported in 1963 when DuBois et al. [20] performed the first-ever LT in WD patient with acute liver failure. The first report of neurological outcome after LT was published in 1973 by Groth et al. [16]. They described a 14-year-old boy with WD, hepatic symptoms, and progressive neurological deterioration (dystonia, choreoathetosis, and dysarthria), despite treatment with d-penicillamine since the age of 11 years. During the first 12 months after LT, neurological symptoms improved and completely resolved within 4 years $[16,17]$. Then in 1983, Zitelli et al. [18] described successful LT in a 13-year-old WD patient, with subsequent resolution of neurological symptoms 15 months after transplantation. These cases, as well as a lack of treatment in severe neurological WD patients, led to several studies of LT in patients with neurological symptoms over the next 40 years.

After initial reports of LT in patients with unresponsive neurological WD, Cheng et al. [42] found that WD patients with neurological symptoms had worse prognosis for survival compared with WD patients without neurological presentation ( $80 \%$ vs. $100 \%$ after 1 year, $60 \%$ vs. $100 \%$ after 3 years and $60 \%$ vs. $89.5 \%$ after 5 years). They documented that the presence of neurological symptoms (especially severe) was a statistically important factor that negatively affected survival after LT (6/15 patients died over the 5-year follow-up). However, it should be noted that the neurological improvement of some degree was observed in all survived WD patients [42].

Similar observations were provided by Medici et al. [50] who reported post-LT overall survival rates of $89 \%$ after 1 year, $82.9 \%$ after 3 years, $75.6 \%$ after 5 years, and $58.8 \%$ after 10 years. Lower survival rates were associated with neuropsychiatric WD presentation (as the authors neurological and psychiatric patients analyzed collectively), with mean survival of 135 months with the hepatic form vs. 79 months in patients with additional neuropsychiatric presentation. Importantly, in 6/7 (85\%) of WD patients with neurological symptoms who survived and were followed up (1 was lost to follow-up), significant improvement of neurological symptoms was observed, with complete resolution of symptoms in two cases [50].

More recent studies involving larger groups of WD patients did not confirm previous observations suggesting worse prognosis in neurological WD patients. Ferrarese et al. [27] and Lankarani et al. [65] did not observe an adverse influence of neurological presentation on survival rates in WD patients after LT. Moreover, these studies documented better long-term general survival rates in transplanted WD patients: $88 \%$ after 1 year and $83 \%$ after 5 years [27]; $86 \%$ after 1 year and $82 \%$ after 5 years [65]. However, contrary to previous reports, in the registry described by Ferrarese et al. [27], no significant improvement of neurological WD patients $(n=10)$ after LT was observed. The Iranian study by 
Lankarani et al. [65] did not confirm that neurological symptoms affected survival, but found improvement of neurological symptoms in almost $67 \%$ of transplanted WD patients. The disparity between older and more recent studies may be due to improvements in transplantology techniques as well as more accurate qualification for LT over time, which has contributed to better results in neurological WD patients.

A recent retrospective analysis of a French registry of LT in WD presented very similar findings to Lankarani et al. [65] and Cheng et al. [42], with general survival rates of $89 \%$ after 1 year and $87 \%$ after 5 years [19]. However, in multivariate analysis, there was a strong statistical trend $(p=0.06)$ toward poorer survival in patients with neurological symptoms [19]. The authors also documented major neurological improvement in $3 / 6$ cases transplanted due to neurological indications, meaning that all WD patients who survived had neurological improvement. The other more recent study performed by Poujois et al. [64] showed better survival results in neurological WD patients $(88.8 \%$ after 1 year and $72.2 \%$ after 3 and 5 years), which are very similar to general populations undergoing LT ( $89 \%$ after 1 year in a French registry). These results clearly demonstrate that each new study with LT in WD patients show better results and survival, also in neurological WD patients, which allows us to be optimistic about the future of LT in WD patients with neurological presentation not responding to anti-copper treatment. Of note, Poujois et al., first used the objective Unified Wilson's Disease Rating Scale (UWDRS) and documented neurological improvement in 8/18 (44\%) of severe neurological patients (bedridden, not responsive to treatment) and in 8/14 (67\%) WD patients who survived. In our opinion, these results are the first to suggest that LT could be an effective treatment in WD patients with severe neurological presentation. The question is when to decide about LT? Sufficient time must be given for anti-copper treatment to work, but it is important not to act too late, when WD progression has caused irreversible brain damage as well as neurological symptoms with contractures and secondary chronic infections.

Discussing the results of case reports, it is worth mentioning that the presented results of LT in WD documented improvement in results in last two decades. Patients who were transplanted more than 20 years ago less frequently achieved significant neurological improvement. These data are consistent with world-wide findings indicating markedly improved post-LT outcomes over the last 30 years [75]. For example, in France, rates of 1-year post-transplant survival increased from $78 \%$ in 1990-1994 to 85\% from 2005-2007 [75]. These results were achieved due to several factors, including better selection of LT candidates, donor selections, organ procurement, surgical techniques, post-operative care, immunosuppression, as well as general patient management [75].
There is a lack of large studies prospectively analyzing the impact of LT on improvement of symptoms and outcome of WD patients with neurological presentation [76]. Data from retrospective studies, case and series reports suggest neurological improvement in $71 \%$ of patients and neurological improvement or stabilization in $78 \%$ of cases. It should be mentioned that WD patients who underwent LT in the reviewed publications had mostly severe neurological deficits and/or liver failure. Although results from the retrospective studies and case reports showed that neurological symptoms are risk factors for worse survival after LT, they were not confirmed in more recent studies [27, 64, 65].

Summarizing, the presented results suggest that LT is a promising method of WD treatment, particularly if patients have not responded to pharmacological de-coppering treatment.

\section{Limitations}

Our literature review has some limitations. Firstly, all 48 papers were retrospective. All studies used various endpoints and methods for their evaluation. Only more recent studies used neurological WD scales (UWDRS) [64] or WD scales developed by Medici et al. [50]. In older studies, only neurological symptoms were described. Further, the studied groups were not homogenous; most of the patients from registries were transplanted due to hepatic indications (mild neurological symptoms), while others, such as the Poujois et al., study and most case reports, were transplanted due to severe neurological deficits. Apart from a few case reports, only Poujois et al. [64] used brain MRI scales for quantitative assessment of the brain. Also, in most of the articles, there was a lack of hepatic assessment according to detailed scales that are useful for LT qualification, such as Model for End-Stage Liver Disease (MELD) or Nazer score, which would be helpful to verify the hepatological indications for LT in neurological patients.

Regarding analyzing the impact of LT on neurological WD symptoms, some of the reported neurological (or neuropsychological/psychiatric) improvements could be due to resolution of hepatic encephalopathy (even subclinically in the case of neuropsychological functioning). Further, we have mentioned, but not analyzed, psychiatric improvement after LT, due to too little data [76, 77]. However, due to the high frequency and clinical significance of psychiatric and cognitive disturbances in WD, this issue should be analyzed separately.

In some of the reviewed studies, chelators or zinc salts were used in addition to LT to remove copper from organs [42, 65]. However, recommendations for such combined treatment are not available [1-3]. 
Finally, there is increasing recognition of the importance of early detection of WD as it has been shown that presymptomatic individuals, when properly treated with anti-copper agents, do not develop clinical symptoms, including neurological symptoms [1-4, 77]. According to WD pathophysiology, neurological symptoms usually occur a few years after hepatic symptoms and many years after the presymptomatic stage of the disease [1-4]. We are currently seeing substantial improvements in WD diagnosis [77-81], including better knowledge of WD by physicians, genetic testing implementation [78-80], and more common family WD screening [4, 80]. There are also suggestions to include neonatal screening for WD using DNA or quantitative assessment of ATP7B protein in dried blood spots [81]. Additionally, new WD treatment modalities are currently under investigation [82] and they may decrease the number of WD patients with neurological presentation [83, 84]. It gives hope that in the near future, discussions surrounding how to treat severely impaired neurological WD patients will be less necessary.

\section{Conclusions}

Currently available data encourage the use of this treatment option, especially in severe neurological patients not responding to anti-copper treatment; however, it is still uncertain which patients with neurological impairment benefit most from LT and when is the optimal timing for LT [77].

Further studies conducted on large cohorts, using neurological and radiological scales as well as potential biomarkers of neurological injury, are needed to establish the role of LT in the treatment of WD with neurological symptoms.

Supplementary Information The online version contains supplementary material available at https://doi.org/10.1007/s13760-022-01872-w.

Funding All financial involvement (e.g., employment, consultancies, honoraria, stock ownership or options, grants, patents received or pending, royalties) with any organization or entity with a financial interest in, or financial conflict with, the subject matter or materials discussed in the submitted publication have been completely disclosed. We have no financial interests relevant to the submitted publication.

Conflict of interest The authors declare no conflict of interest.

Open Access This article is licensed under a Creative Commons Attribution 4.0 International License, which permits use, sharing, adaptation, distribution and reproduction in any medium or format, as long as you give appropriate credit to the original author(s) and the source, provide a link to the Creative Commons licence, and indicate if changes were made. The images or other third party material in this article are included in the article's Creative Commons licence, unless indicated otherwise in a credit line to the material. If material is not included in the article's Creative Commons licence and your intended use is not permitted by statutory regulation or exceeds the permitted use, you will need to obtain permission directly from the copyright holder. To view a copy of this licence, visit http://creativecommons.org/licenses/by/4.0/.

\section{References}

1. European Association For The Study of The Liver Disease (2012) EASL clinical practice guidelines: Wilson's disease. J Hepatol 56:671-685. https://doi.org/10.1016/j.jhep.2011.11.007

2. Roberts E, Schilsky M (2008) Diagnosis and treatment of Wilson disease: an update. Hepatology 47:2089-2111. https://doi.org/10. 1002/hep. 22261

3. Członkowska A, Litwin T, Dusek P, Ferenci P, Lutsenko S, Medici V, Rybakowski JK, Weiss KH, Schilsky ML (2018) Wilson disease. Nat Rev Dis Primers 6:21. https://doi.org/10.1038/ s41572-018-0018-3

4. Socha P, Janczyk W, Dhawan A, Baumann U, D'Antiga L, Tanner S, Iorio R, Vajro P, Houwen R, Fischler B, Dezsofi A, Hadzic N, Hierro L, Jahnel J, McLin V, Nobili V, Smets F, Verkade HJ, Debray D (2018) Wilson's disease in children: a position paper by the Hepatology Committee of the European Society for Paediatric Gastroenterology, Hepatology and Nutrition. J Pediatr Gastroenterol Nutr 66:334-344. https://doi.org/10.1097/ MPG.0000000000001787

5. Nagral A, Sarma MS, Matthai J, Kukkle PL, Devarbhavi H, Sinha S, Alam S, Bavdekar A, Dhiman RK, Eapen CE, Goyal V, Mohan N, Kandadai RM, Sathiyasekaran M, Poddar U, Sibal A, Sankaranarayanan S, Srivastava A, Thapa BR, Wadia PM, Yachha SK, Dhawan A (2019) Wilson's disease: clinical practice guidelines of the Indian National Association for Study of the Liver, the Indian Society of Pediatric Gastroenterology, Hepatology and Nutrition, and the Movement Disorders Society of India. J Clin Exp Hepatol 9:74-98. https://doi.org/10.1016/j. jceh.2018.08.009

6. Czlonkowska A, Litwin T, Karlinski M, Dziezyc K, Chabik G, Czerska M (2014) D-penicillamine versus zinc sulfate as first-line therapy for Wilson's disease. Eur J Neurol 21:599-606. https:// doi.org/10.1111/ene. 12348

7. Svetel M, Pekmezovic T, Petrovic I, Tomic A, Kresojevic N, Jesic R, Kazic S, Raicevic R, Stefanovic D, Delibasic N, Zivanovic D, Dordevic M, Kostic VS (2009) Long-term outcome in Serbian patients with Wilson disease. Eur J Neurol 16:852-857. https:// doi.org/10.1111/j.1468-1331.2009.02607.x

8. Czlonkowska A, Tarnacka B, Litwin T, Gajda J, Rodo M (2005) Wilson's disease-cause of mortality in 164 patients during 1992 2003 observation period. J Neurol 252:698-703. https://doi.org/ 10.1007/s00415-005-0720-4

9. Litwin T, Dzieżyc K, Karliński M, Chabik G, Czepiel W, Czlonkowska A (2015) Early neurological worsening in patients with Wilson's disease. J Neurol Sci 355:162-167. https://doi.org/ 10.1016/j.jns.2015.06.010

10. Litwin T, Dusek P, Czlonkowska A (2017) Symptomatic treatment of neurologic symptoms in Wilson disease. Handb Clin Neurol 142:211-223. https://doi.org/10.1016/B978-0-444-63625-6. 00018-5

11. Bruha R, Marecek Z, Pospilova L, Nevsimalova S, Vitek L, Martasek P, Nevoral J, Petrtyl J, Urbanek P, Jiraskova A, Ferenci P (2011) Long-term follow-up of Wilson disease: natural history, treatment, mutations analysis and phenotypic correlation. Liver Int 31:83-91. https://doi.org/10.1111/j.1478-3231.2010.02354.x

12. Beinhardt S, Leiss W, Stattermayer AF, Graziadei I, Zoller H, Stauber R, Maieron A, Datz C, Steindl-Munda P, Hofer H, Vogel W, Trauner M, Ferenci P (2014) Long-term outcomes of patients 
with Wilson disease in a large Austrian cohort. Clin Gastroenterol Hepatol 12:683-689. https://doi.org/10.1016/j.cgh.2013.09.025

13. Schilsky ML (2014) Long-term outcome for Wilson disease: $85 \%$ good. Clin Gastroenterol Hepatol 12:690-691. https://doi.org/10. 1016/j.cgh.2013.11.009

14. Yuan XZ, Yang RM, Wang XP (2021) Management perspective of Wilson's disease: early diagnosis and individualized therapy. Curr Neuropharmacol 19:465-485. https://doi.org/10.2174/15701 59X18666200429233517

15. Bandmann O, Weiss KH, Hedera P (2020) Liver transplant for neurologic Wilson disease: Hope or fallacy? Neurology 94:907908. https://doi.org/10.1212/WNL.0000000000009476

16. Groth CG, Dubois RS, Corman J (1973) Metabolic effects of hepatic replacement in Wilson's disease. Transpl Proc 5:829-833

17. Beart RW, Putnam CW, Porter KA, Starzl TE (1975) Liver transplantation for Wilson's disease. Lancet 2:176-177. https://doi.org/ 10.1016/s0140-6736(75)90077-x

18. Zittelli BJ, Malatack JJ, Gartner JC Jr, Shaw BW, Iwatsuki S, Starzl TE (1983) Orthotopic liver transplantation in children with hepatic-based metabolic disease. Transpl Proc 15:1284-1287

19. Guillaud O, Dumortier J, Sobesky R, Debray D, Wolf P, Vanlemmens C, Durand F, Calmus Y, Duvoux C, Dharancy S, Kamar N, Boudjema K, Bernard PH, Pageaux GP, Salamé E, Gugenheim J, Lachaux A, Habes D, Radenne S, Hardwigsen J, Chazouillères O, Trocello JM, Woimant F, Ichai P, Branchereau S, Soubrane O, Castaing D, Jacquemin E, Samuel D, Duclos-Vallée JC (2014) Long term results of liver transplantation for Wilson's disease: experience in France. J Hepatol 60:579-589. https://doi.org/10. 1016/j.jhep.2013.10.025

20. DuBois RS, Rodgerson DO, Martineau G, Shroter G, Giles G, Lilly J, Halgrimson CG, Starzl TE, Sternlieb I, Scheinberg IH (1971) Orthotopic liver transplantation for Wilson's disease. Lancet 1:505-508. https://doi.org/10.1016/s0140-6736(71)91121-4

21. Yoshitoshi EY, Takada Y, Oike F, Sakamoto S, Ogawa K, Kanazawa H, Ogura Y, Okamoto S, Haga H, Ueda M, Egawa H, Kasahara M, Tanaka K, Uemoto S (2007) Long-term outcomes for 32 cases of Wilson's disease after living donor liver transplantation. Transplantation 87(2009):261-267. https://doi.org/10.1097/TP. 0b013e3181919984

22. Marin C, Robles R, Parilla G, Ramirez P, Bueno FS, Parilla P (2007) Liver transplantation in Wilson's disease: are its indication established? Transpl Proc 39:2300-2301. https://doi.org/10. 1016/j.transproceed.2007.06.039

23. Wang XH, Zhang F, Li XC, Cheng F, Li J, Li GQ, Huang J (2004) Eighteen living related liver transplants for Wilson's disease: a single-center. Transpl Proc 36:2243-2245. https://doi.org/10. 1016/j.transproceed.2004.06.029

24. Lui CC, Chen CL, Cheng YF, Lee TY (1998) Recovery of neurological deficits in a case of Wilson's disease after liver transplantation. Transpl Proc 30:3324-3325. https://doi.org/10.1016/ s0041-1345(98)01048-3

25. Chen CL, Chen YS, Lui CC, Hsu SP (1997) Neurological improvement of Wilson's disease after liver transplantation. Transpl Proc 29:497-498. https://doi.org/10.1016/s0041-1345(96)00225-4

26. Bellary S, Hassnein T, Van Thiel DH (1995) Liver transplantation for Wilson's disease. J Hepatol 23:373-381. https://doi.org/10. 1016/0168-8278(95)80194-4

27. Ferrarese A, Morelli MC, Carrai P, Milana M, Angelico M, Perricone G, Belli LS, Marrone G, Grieco A, Martini S, Manini MA, Fagiuoli S, Toniutto P, Galeota Lanza A, Bhoori S, Petta S, Giannini EG, Burra P (2020) Outcomes of liver transplant for adults with Wilson's disease. Liver Transpl 26:507-516. https://doi.org/ 10.1002/1t.25714

28. Ocal R, Ayvazoglu Soy EH, Benli S, Donmez F, Ağıldere M, Ocal S, Haberal M (2020) Effect of liver transplant on neurologic manifestations and brain magnetic resonance imaging findings in
Wilson disease. Exp Clin Transpl 18:84-87. https://doi.org/10. 6002/ect.TOND-TDTD2019.P29

29. Ronghua T, Zheng X, Qifa Y (2002) Wilson's disease and hepatic transplantation. J Huazhong Univ Sci Technol Med Sci 22:142-143

30. Polson RJ, Rolles K, Calne RY, Williams R, Marsden D (1987) Reversal of severe neurological manifestations of Wilson's disease following orthotopic liver transplantation. Q J Med 244:685-691

31. Mason AL, Marsh W, Alpers DH (1993) Intractable neurological Wilson's disease treated with orthotopic liver transplantation. Dig Dis Sci 38:1746-1750. https://doi.org/10.1007/BF01303186

32. Kassam N, Witt N, Kneteman N, Bain VG (1998) Liver transplantation for neuropsychiatric Wilson disease. Can J Gastroenterol 12:65-68. https://doi.org/10.1155/1998/414236

33. Choudhary NS, Saigal S, Saraf N, Rastogi A, Goja S, Bhangui P, Thiagrajan S, Gautam D, Govil D, Vohra V, Soin AS (2018) Outcome of living donor liver transplantation for Wilson's disease in adults: a single center experience. J Clin Exp Hepatol 8:132-135. https://doi.org/10.1016/j.jceh.2017.11.003

34. Walker G, Hussaini T, Stowe R, Cresswell S, Yoshida EM (2018) Liver transplant can resolve severe neuropsychiatric manifestations of Wilson disease: a case report. Exp Clin Transpl 16:620-624. https://doi.org/10.6002/ect.2016.0053

35. Laurencin C, Brunet AS, Dumortier J, Lion-Francois L, Thobois S, Mabrut JY, Dubois R, Woimant F, Poujois A, Guillaud O, Lachaux A, Broussolle E (2017) Liver transplantation in Wilson's disease with neurological impairment: evaluation in 4 patients. Eur Neurol 77:5-15. https://doi.org/10.1159/00045 2658

36. Yagci MA, Tardu A, Karagul S, Ertugrul I, Ince V, Kirmizi S, Unal B, Isik B, Kayaalp C, Yilmaz S (2015) Influence of liver transplantation on neuropsychiatric manifestations of Wilson disease. Transpl Proc 47:1469-1473. https://doi.org/10.1016/j.trans proceed.2015.04.017

37. Sutariya VK, Tank AH, Modi PR (2015) Orthotropic liver transplantation for intractable neurological manifestations of Wilson's disease, Saudi. J Kidney Dis Transpl 26:556-559. https://doi.org/ 10.4103/1319-2442.157365

38. Mocchegiani F, Gemini S, Vincenzi P, Montalti R, Vecchi A, Nicolini D, Federici A, Coletta M, Pansini M, Lanari J, Svegliati Baroni G, Risaliti A, Vivarelli M (2014) Liver transplantation in neurological Wilson's Disease: is there indication? A casr report. Transpl Proc 46:2360-2364. https://doi.org/10.1016/j.transproce ed.2014.07.059

39. Dou K, Wang D, Tao K, Yue S, Ti Z, Song Z, Li L, He Y, Hou X (2014) A modified heterotopic auxiliary living donor liver transplantation: report of a case. Ann Hepatol 13:399-403

40. Weiss KH, Schäfer M, Gotthardt DN, Angerer A, Mogler C, Schirmacher P, Schemmer P, Stremmel W, Sauer P (2013) Outcome and development of symptoms after orthotopic liver transplantation for Wilson disease. Clin Transpl 27:914-922. https://doi.org/ 10.1111/ctr.12259

41. Peedikayil MC, Al Ashgar HI, Al Mousa A, Al Sebayel M, Al Kahtani K, Alkhail FA (2013) Liver transplantation in Wilson's disease: Single center experience from Saudi Arabia, World. J Hepatol 5:127-132. https://doi.org/10.4254/wjh.v5.i3.127

42. Cheng F, Li GQ, Zhang F, Li XC, Sun BC, Kong LB, Pu LY, Wang K, Qian XF, You W, Wang XH (2009) Outcomes of livingrelated liver transplantation for Wilson's disease: a single-center experience in China. Transplantation 87:751-757. https://doi.org/ 10.1097/TP.0b013e318198a46e

43. Duarte-Rojo A, Zepeda-Gómez S, García-Leiva J, Remes-Troche JM, Angeles-Angeles A, Torre-Delgadillo A, Olivera-Martínez MA (2009) Liver transplantation for neurologic Wilson's disease: reflections on two cases within a Mexican cohort. Rev Gastroenterol Mex 74:218-223 
44. Park YK, Kim BW, Wang HJ, Kim MW (2008) Auxiliary partial orthotopic living donor liver transplantation in a patient with Wilson's disease: a case report. Transpl Proc 40:3808-3809. https:// doi.org/10.1016/j.transproceed.2008.07.128

45. Pabón V, Dumortier J, Gincul R, Baulieux J, Ducerf C, Trépo C, Souquet JC, Zoulim F, Paliard P, Boillot O, Bost M, Lachaux A (2008) Long-term results of liver transplantation for Wilson's disease. Gastroenterol Clin Biol 32:378-381. https://doi.org/10. 1016/j.gcb.2008.01.033

46. Martin AP, Bartels M, Redlich J, Hauss J, Fangmann J (2008) A single-center experience with liver transplantation for Wilson's disease. Clin Transpl 22:216-221. https://doi.org/10.1111/j.13990012.2007.00777.x

47. Sevmis S, Karakayali H, Aliosmanoglu I, Yilmaz U, Ozcay F, Torgay A, Arslan G, Haberal M (2008) Liver transplantation for Wilson's disease. Transpl Proc 40:228-230. https://doi.org/10. 1016/j.transproceed.2007.11.007

48. Suess T, Bokemeyer M, Schomerus G, Donnerstag F, Manns MP, Klempnauer J, Kolbe H, Weissenborn K (2007) Video documented follow-up of liver transplantation in Wilson's disease with predominant neurological manifestation. Mov Disord 22:1036-1038. https://doi.org/10.1002/mds.21444

49. Senzolo M, Loreno M, Fagiuoli S, Zanus G, Canova D, Masier A, Russo FP, Sturniolo GC, Burra P (2007) Different neurological outcome of liver transplantation for Wilson's disease in two homozygotic twins. Clin Neurol Neurosurg 109:71-75. https:// doi.org/10.1016/j.clineuro.2006.01.008

50. Medici V, Mirante VG, Fassati LR, Pompili M, Forti D, Del Gaudio M, Trevisan CP, Cillo U, Sturniolo GC, Fagiuoli S, Monotematica AISF (2000) OLT Study Group (2005) Liver transplantation for Wilson's disease: The burden of neurological and psychiatric disorders. Liver Transpl 11:1056-1063. https:// doi.org/10.1002/1t.20486

51. Wang XH, Cheng F, Zhang F, Li XC, Kong LB, Li GQ, Li J, Qian XF (2005) Living-related liver transplantation for Wilson's disease. Transpl Int 18:651-656. https://doi.org/10.1111/j.14322277.2004.00074.x

52. Wang XH, Zhang F, Li XC, Cheng F, Li J, Li GQ, Huang J (2004) Eighteen living related liver transplants for Wilson's disease: a single-center. Transpl Proc 36:2243-2245. https:// doi.org/10.1016/j.transproceed.2004.06.029

53. Geissler I, Heinemann K, Rohm S, Hauss J, Lamesch P (2003) Liver transplantation for hepatic and neurological Wilson's disease. Transpl Proc 35:1445-1446. https://doi.org/10.1016/ s0041-1345(03)00464-0

54. Suzuki S, Sato Y, Ichida T, Hatakeyama K (2003) Recovery of severe neurologic manifestations of Wilson's disease after living-related liver transplantation: a case report. Transpl Proc 35:385-386. https://doi.org/10.1016/s0041-1345(02)03855-1

55. Hermann W, Eggers B, Wagner A (2002) The indication for liver transplant to improve neurological symptoms in a patient with Wilson's disease. J Neurol 249:1733-1734. https://doi.org/ 10.1007/s00415-002-0867-1

56. Wu JC, Huang CC, Jeng LB, Chu NS (2000) Correlation of neurological manifestations and MR images in a patient with Wilson's disease after liver transplantation. Acta Neurol Scand 102:135-139. https://doi.org/10.1034/j.1600-0404.2000.10200 2135.x

57. Stracciari A, Tempestini A, Borghi A, Guarino M (2000) Effect of liver transplantation on neurological manifestations in Wilson disease. Arch Neurol 57:384-386. https://doi.org/10.1001/ archneur.57.3.384

58. Eghtesad B, Nezakatgoo N, Geraci LC, Jabbour N, Irish WD, Marsh W, Fung JJ, Rakela J (1999) Liver transplantation for Wilson's disease: a single-center experience. Liver Transpl Surg 5:467-474. https://doi.org/10.1002/lt.500050614
59. Bax RT, Hässler A, Luck W, Hefter H, Krägeloh-Mann I, Neuhaus P, Emmrich P (1998) Cerebral manifestation of Wilson's disease successfully treated with liver transplantation. Neurology 51:863-865. https://doi.org/10.1212/wnl.51.3.863

60. Schumacher G, Platz KP, Mueller AR, Neuhaus R, Steinmüller T, Bechstein WO, Becker M, Luck W, Schuelke M, Neuhaus P (1997) Liver transplantation: treatment of choice for hepatic and neurological manifestation of Wilson's disease. Clin Transpl $11: 217-224$

61. Guarino M, Stracciari A, D'Alessandro R, Pazzaglia P (1995) No neurological improvement after liver transplantation for Wilson's disease. Acta Neurol Scand 92:405-408. https://doi.org/ 10.1111/j.1600-0404.1995.tb00155.x

62. Schilsky ML, Scheinberg IH, Sternlieb I (1994) Liver transplantation for Wilson's disease: indications and outcome. Hepatology 19:583-587. https://doi.org/10.1002/hep.1840190307

63. Castellano G, Blasco A, Ballesta F, Colina F, Moreno D, Franch O, Urruzuno P, Solís JA (1992) Wilson's disease. A retrospective analysis of 12 cases. Rev Clin Esp 190:223-228

64. Poujois A, Sobesky R, Meissner WG, Brunet AS, Broussolle E, Laurencin C, Lion-François L, Guillaud O, Lachaux A, Maillot F, Belin J, Salamé E, Vanlemmens C, Heyd B, Bellesme C, Habes D, Bureau C, Ory-Magne F, Chaine P, Trocello JM, Cherqui D, Samuel D, de Ledinghen V, Duclos-Vallée JC, Woimant F (2020) Liver transplantation as a rescue therapy for severe neurologic forms of Wilson disease. Neurology 94:e2189-e2202. https://doi. org/10.1212/WNL.0000000000009474

65. Lankarani KB, Malek-Hosseini SA, Nikeghbalian S, Dehghani M, Pourhashemi M, Kazemi K, Janghorban P, Akbari M, Ghahramani S, Eghtesad B, Moini M, Rahmi Jaberi A, Shamsaifar A, Gholami S, Rahmanian F, Geramizadeh B (2016) Fourteen years of experience of liver transplantation for Wilson's disease; a report on 107 cases from Shiraz, Iran. PLoS ONE 11:e0167890. https://doi.org/ 10.1371/journal.pone.0167890

66. Tang R, Xue Z, Ye Q (2002) Wilson's disease and hepatic transplantation. J Huazhong Univ Sci Technol Med Sci 22:142-143. https://doi.org/10.1007/BF02857678

67. Tison F, Rouanet F, Neau-Cransac M, Carles J, Couzigou P (1996) Outcome of liver transplantation in Wilson's disease: a demonstrative case. Parkinsonism Relat Disord 2:131-135. https://doi.org/ 10.1016/1353-8020(96)00008-9

68. Hefter H, Rautenberg W, Kreuzpaintner G, Arendt G, Freund HJ, Pichlmayr R, Strohmeyer G (1991) Does orthotopic liver transplantation heal Wilson's disease? Clinical follow-up of two livertransplanted patients. Acta Neurol Scand 84:192-196. https://doi. org/10.1111/j.1600-0404.1991.tb04936.x

69. Haberal M, Akdur A, Moray G, Boyacioglu S, Torgay A, Arslan G, Handan Ozdemir B (2017) Auxillary partial orthotopic living liver transplant for Wilson disease. Exp Clin Transpl 15(Suppl 1):182-184. https://doi.org/10.6002/ect.mesot2016.P64

70. Kim JS, Kim SY, Choi JY, Kim HT, Oh YS (2014) Delayed appearance of wing-beating tremor after liver transplantation in a patient with Wilson disease. J Clin Neurosci 21:1460-1462. https://doi.org/10.1016/j.jocn.2013.10.036

71. Öcal R, Öcal S, Kırnap M, Moray G, Haberal M (2018) Complications of liver transplant in adult patients with the hepatic form of Wilson disease. Exp Clin Transpl 16(Suppl 1):38-40

72. Erol I, Alehan F, Ozcay F, Canan O, Haberal M (2008) Neurologic complications of liver transplantation in pediatric patients with the hepatic form of Wilson's disease. J Child Neurol 23:293-300. https://doi.org/10.1177/0883073807309233

73. Litwin T, Gromadzka G, Członkowska A (2008) Neurological presentation of Wilson's disease in a patient after liver transplantation. Mov Disord 23:743-746. https://doi.org/10.1002/mds. 21913 
74. Liberati A, Altman DG, Tetzlaff J, Mulrow C, Gotzsche PC, Ioannidis JP, Clarke M, Devereaux PJ, Kleijnen J, Moher D (2009) The PRISMA statement for reporting systematic reviews and meta-analyses of studies that evaluate health care interventions. Explanation and elaboration. Ann Intern Med 151:W65-W94. https://doi.org/10.7326/0003-4819-151-4-200908180-00136

75. Durand F (2018) How to improve long-term outcome after liver transplantation. Liver Int 38(Suppl 1):134-138. https://doi.org/ 10.1111/liv. 13651

76. Sorbello O, Riccio D, Sini M, Carta M, Demelia L (2011) Resolved psychosis after liver transplantation in patient with Wilson's disease. Clin Pract Epidemiol Ment Health 7:182-184. https://doi.org/10.2174/1745017901107010182

77. Ferrarese A, Burra P (2021) The need for consensus about liver transplantation for patients with neuropsychiatric Wilson's disease. Prog Transplant 31:168-170. https://doi.org/10.1177/15269 248211002806

78. Dzieżyc K, Karliński M, Litwin T, Członkowska A (2014) Compliant treatment with anti-copper agents prevents clinically overt Wilson's disease in pre-symptomatic patients. Eur J Neurol 21:332-337. https://doi.org/10.1111/ene.12320

79. Stattermayer AF, Entenmann A, Gschwantler M, Zoller H, Hofer H, Ferenci P (2019) The dilemma to diagnose Wilson disease by genetic testing alone. Eur J Clin Invest 49:e13147. https://doi.org/ 10.1111/eci.13147
80. Antos A, Litwin T, Skowrońska M, Kurkowska-Jastrzębska I, Członkowska A (2020) Pitfalls in diagnosing Wilson's Disease by genetic testing alone: the case of a 47-year-old woman with two pathogenic variants of the ATP7B gene. Neurol Neurochir Pol 54:478-480. https://doi.org/10.5603/PJNNS.a2020.0063

81. Espinos C, Ferenci P (2020) Are the new genetic tools for diagnosis of Wilson disease helpful in clinical practice? JHEP Rep 2:100114. https://doi.org/10.1016/j.jhepr.2020.100114

82. Li H, Tao R, Liu L, Sgiquiang S (2019) Population screening and diagnostic strategies in screening family members of Wilson's disease patients. Ann Transl Med 7(Suppl 2):S59. https://doi.org/ 10.21037/atm.2019.03.54

83. Litwin T, Dzieżyc K, Członkowska A (2019) Wilson diseasetreatment perspectives. Ann Transl Med 7(Suppl 2):S68. https:// doi.org/10.21037/atm.2018.12.09

84. Członkowska A, Litwin T, Kraiński Ł, Skowrońska M, Piechal A, Antos A, Niewada M (2021) Long term follow-up of Wilson disease patients in Poland Report from the national reference centre. Mov Disord 36(1):S508-S550. https://doi.org/10.1002/mds.28794

Publisher's Note Springer Nature remains neutral with regard to jurisdictional claims in published maps and institutional affiliations. 